\title{
The Renfrew Word Finding Scale : Application to the South African Context
}

\author{
Jenny Pahl \\ Meenakumari B. Kara \\ Department of Speech and Hearing Therapy \\ University of Durban-Westville, Durban
}

\begin{abstract}
The Renfrew Word Finding Scale (Renfrew, 1988) was administered to 30 Indian (Group A) and 30 White (Group B) Durban English speaking children aged between eight and nine years to determine its suitability for assessment of expressive vocabulary. Mean scores for both groups were statistically compared to the British norms in terms of mean raw scores and mean mental age. Mean scores for groups $A$ and $B$ were compared to each other. Item analyses were carried out to obtain further information regarding possible lexical characteristics for each group and common problems with certain items. Both groups performed significantly poorer than expected according to the British norms. Group A was significantly lower than Group B, thus indicating the test's unsuitability for use with these population groups in its present form.
\end{abstract}

\section{OPSOMMING}

Die "Renfrew Word Finding Scale" (Renfrew, 1988) is op 30 Indiër (Groep A) en 30 Blanke (Groep B) Engelssprekende kinders tussen die ouderdomme agt en nege jaar, woonagtig in Durban, getoets om hierdie toets se toepasbaarheid vir die bepaling van ekspressiewe woordeskat vas te stel. Die gemiddelde tellings vir beide groupe is statisties vergelyk met die Britse norme ten opsigte van gemiddelde routellings en gemiddelde verstandsouderdom. Gemiddelde tellings vir Group A en B is ook met mekaar vergelyk. Itemanalise is uitgevoer om verdere inligting aangaande moontlike leksikale kenmerke vir elke afsonderlike groep, sowel as gemeenskaplike probleme van sekere items te verkry. Beide groepe het beduidend swakker as wat verwag was, ten opsig van die Britse norme presteer, en Groep A was beduidend laer as Groep B. Die resultate dui dus daarop dat die huidige toets nie toepaslik is vir hierdie populasie groepe nie.

The,introduction of the new dispensation in South Africa has resulted in many changes to its society, including the opportunity for the admission and integration of different ethnic groups within the school system. This integration has implications for speech therapists, who will increasingly be required to provide services to people of language and cultural backgrounds different from their own. At present the framework for this service, both theoretical and practical, is primarily Euro-American in nature (Taýlor, 1986), and not always appropriate to the South African context.

An important part of the speech therapist's provision of services is assessment, which is aimed at differentiating between those people presenting with a communication problem and those whose communication is adequate. According to Malan (1981), recent sociolinguistic research concerning normative differences in the language of children has necessitated a reevaluation of the current approaches to the assessment and diagnosis of language disorders in South Africa'. She has stressed the importance of obtaining normative information pertaining to specific communities because the commonly used measures of linguistic behaviour are based on the norms of the mainstream language. This has great significance in differentiating between true language pathology and language difference or variation. By failing to make the distinction, a difference could be perceived as a disorder, which would constitute a misdiagnosis, and could result in inappropriate and unnecessary therapy (Anderson, 1984). The need for appropriately norm-referenced techniques in the assessment process is therefore explicit (Alant \& Beukes, 1986). The acknowledgement of cultural factors contributed to the differencedeficit controversy concerning language. The deficit theory holds in America, for example, that "Black" English is inferior to standard or "White" English. In contrast, the difference theory (e.g., Labov, 1968; Baratz \& Povitch, 1967, cited by Williams 1970) holds that all languages and dialects are equal.

The use of standardised tests in the assessment process can provide useful and reliable information, but in the South African situation it is frequently fraught with problems. One of the acknowledged major limitations of standardised tests is that of test bias. Adler (1979) has outlined ways in which tests can be biased towards culturally different children, including the bias of linguistic aspects, the bias of non-linguistic factors, a culture-specific verbal style being required by the test, and bias due to the test's being outside the general experience of the testee. Jensen (1980) discussed test bias in terms of the content validity of test items and the standardisation population. A test user, such as a speech therapist, may subjectively evaluate the appropriateness of the test according to these aspects, and may judge the test itself as culturally biased. Such subjective judgments should be investigated.

In the multilingual and multicultural South African con- 
text, there are obviously many problems encountered by speech therapists in assessment in general and in particular, when using standardised tests. The implications of these difficulties include the provision of inadequate or inappropriate services, especially when working with people from different cultural backgrounds. Alant and Beukes (1986) have stressed that the limitations of standardised tests for use with different populations should be recognised, and effort should be made to reduce or eliminate the cultural and socioeconomic biases in these tests. This can be done by renorming existing tests, adapting test items or developing local norms (see, for example the discussion about this by Vaughn-Cooke, 1983).

An aspect of communication frequently assessed by speech therapists is language development. The content component, one of three language components proposed by Bloom and Lahey (1978), encompasses meaning or semantics (Owens, 1988). In this paper, the focus will be on an important subcomponent of language content, vocabulary. The acquisition of vocabulary, which is an integral aspect of language development, is never complete (Rees, 1980) and a person's lexicon continues to expand throughout life (Owens, 1988). Jensen (1980) has stated that the acquisition of word meanings is highly dependent on the context in which the words are encountered. Furthermore, vocabulary is not acquired by rote memorisation or formal instruction, but through generalisation, discrimination, education and inference. The child thus acquires the vocabulary of his/her cultural group (Jensen, 1980). Many researchers have documented the gradual (Leonard \& Fey, 1979) but rapid and extensive acquisition of vocabulary (John \& Goldstein, 1964; Owens, 1988). Effective communication is dependent upon the retrieval of lexical items coding this knowledge from stored memory. According to Wiig and Semel (1984), in attempts to recall a word from long term memory, several processes are necessary. These include the selection of concepts and relationships to match the ideas, attitudes and feelings to be expressed; and the selection of vocabulary equivalents for the targeted concepts and relationships.

The speech therapist is frequently concerned with the assessment of vocabulary development in children, for which (s)he uses standardised tests. Although various tests are available, few if any have been standardised for the language and dialect groups in South Africa. The Renfrew Word Finding Scale (RWFS) developed by Renfrew (1968) in Britain is one such test, that is widely used by speech therapists in Durban for assessing expressive vocabulary. Such assessment is valuable in identifying language difficulties in children (Cottrell, Montague, Farb \& Thorne, 1980), but if cultural influences and differences are not considered, such testing can be problematic. Since the first edition of the RWFS, published in 1968 , there have been two revisions with the third edition having been published in 1988 (Renfrew, 1988). A survey of the literature reveals that there are no reported studies on the application of this test to different cultural and ethnic groups in South Africa. From the above, it appears that the relevance of the British norms and individual test items is questionable and should be examined to ensure accurate assessment of expressive vocabulary. The purpose of this study was thus to investigate the suitability of this British test of expressive vocabulary for a group of English speaking Indian and White children between eight and nine years of age in Durban.

\section{METHODOLOGY}

\section{Aims}

The primary aim of this study was to obtain information on the performance of English speaking Indian (Group A) and
White (Group B) children to determine the suitability of the RWFS by comparing the performance of both groups with the British norms; and by comparing the results of the two groups to identify possible cultural and ethnic group influences on test performance. The secondary aim was to carry out a qualitative and quantitative item analysis to investigate the suitability of the test items, and to explore the possibility of specific vocabulary characteristics of both groups.

\section{Subjects}

1. Description of subjects. The subjects were 30 South African Indian (Group A) and 30 South African White (Group B) children, 15 males and 15 females in each group. The subjects ranged in age from eight to nine years.

2. Subject selection criteria. Renfrew $(1968 ; 1972 ; 1988)$ selected subjects for the standardisation of the RWFS on the basis of the criteria that all children should be between the ages of three and nine years; be from English speaking homes; and have normal speech and language abilities. The same criteria were utilised in this study with the following modifications. Due to practical limitations, subjects in this study were between eight and nine years of age. This age range was chosen as it was predicted that, as this level is the highest chosen by Renfrew (1988), the subjects would be able to attempt all items included in the test, thereby providing the maximum amount of information regarding the suitability of items. Equal numbers of boys and girls were chosen in each group to note if there were significant differences in scores obtained due to the sex variable, as Renfrew (1988) indicated a sex difference with regard to scores obtained. Any subject who had failed a year at school was excluded from the study. All subjects were required to be judged by their teachers as being of normal intelligence and as having normal speech and language abilities. Although Renfrew (1988) did not control for the class variable, subjects for this study were chosen from the middle socioeconomic group to exclude a possible source of differences. Adler (1979) has noted that values relating to class cultures are reflected in linguistic interactions between children and their families, which could lead to class differences in linguistic development.

\section{Apparatus}

The standardised test materials of the RWFS (1988) were used. The RWFS is utilised to assess children's ability to use words in a picture naming task. The test consists of 45 black and white line drawings on separate cards requiring 50 naming responses, which are scored on a recording form.

\section{Procedure}

All subjects at each of the schools were tested in the same room in the respective schools with only the subject and examiner present. The RWFS was administered with the examiner seated at a table next to the subject in a single session, lasting 10-15 minutes. Administration and scoring procedures as outlined in the test manual were utilised. If the child was unable to recognise a picture or a targeted part, therefore, suitable explanations were given (Renfrew, 1988, p.6). A modification to this procedure was to use all test items, as opposed to beginning at the starting points (items 17 and 26) for the age groups under study, in order to achieve the aim of evaluating the suitability of test items.

\section{Analysis of Data}

1. After administration of the test, a raw score representing the total number of correct responses, was obtained for each subject according to the scoring procedures outlined in the 
RWFS manual. Using informal inspection, the mean raw scores for Groups A and B were compared to the norms. The raw scores were converted to derived age level scores (referred to as mental age in this study for convenience) and mean mental ages were calculated for males and females in each group.

2. To determine if there were significant differences and variations between mean scores obtained by each group and the standardised British norms due to differences in sex, ethnic group and the interaction between these two variables (K.C. Ryan, personal communication, April, 1991), a two-way analysis of variance (ANOVA) was calculated. Further, to identify differences within the ethnic groups (South African Indian, White, and British), the Tukey Test, HSD (honestly significant difference) which is a $Q$ post hoc test, was done.

3. To check for significant differences between mean mental age and mean chronological age for Groups $A$ and $B$, the Student's t-ratio test for correlated data was used. Further, a ttest was used to determine if there was a significant difference between the mean mental age scores obtained by the South African groups.

4. Quantitative and qualitative item analyses were carried out on the responses of the subjects on the RWFS in an attempt to obtain information about their familiarity with the items as well as characteristics of South African Indian English (SAIE) and South African English (SAE). Adler (1979, p.88) has sug- gested the use of this procedure with different ethnic groups to "compare a child's linguistic performance to both standard and peer group norms". This will provide information concerning the difficulty of the item (Downie \& Heath, 1974).

\section{RESULTS}

1. Informal inspection of Groups $A$ and $B$ scores in comparison to British norms. The average raw scores of both Groups $A$ and $B$ were equivalent to the scores obtained by younger children in the standardisation sample. Group A (Indian) obtained scores equivalent to the 5.6 to 6.0 year old age level, which is approximately 2.6 to 3.0 years below mean CA, while Group B (White) obtained scores equivalent to the 7.0 to 7.6 year old age level, which is approximately 1.6 to 2.0 years below mean CA.

2. Statistical comparison of the performance of the South African Groups to the British norms. These results are presented in Table 1 . A significant difference $(p<.05)$ in performance on the RWFS between the South African and British populations was found due to the ethnic group variable (see Table 1). The results of the post-hoc test revealed that a significant difference occurred between the three ethnic groups. The sex variable was not found to be significant ( $p>.05$ ) in all ethnic groups, and the combined effects of ethnic

Table 1: ANOVA for scores obtained by Groups $A$ and B compared to the standardised scores on the RWFS (1988)

\begin{tabular}{|l|c|c|c|c|c|c|}
\hline Source & SS & MS & df & F & P-value & p-level \\
\hline ethnic group & 1372.422 & 686.211 & 2 & 53.51 & 0.000 & $\mathrm{p}<.05$ \\
\hline sex & 25.600 & 25.600 & 1 & 1.996 & 0.161 & $\mathrm{p}>.05$ \\
\hline ethnic group and sex & 0.067 & 0.033 & 2 & 0.003 & 0.997 & $\mathrm{p}>.05$ \\
\hline
\end{tabular}

KEY: SS - sum of squares

MS - mean squares

$\mathrm{df}$ - degree of freedom
$\mathrm{F}-\mathrm{F}$ value

p-value - probability values

P-level - probability level

Table 2: Comparison of mean MA to mean CA scores on the RWFS for Groups A and B

\begin{tabular}{|c|c|c|c|c|c|c|c|c|}
\hline Group & MCA & MMA & M-d & SD-d & df & $\mathrm{t}$ & $\mathrm{p}$-value & $\mathrm{p}$-level \\
\hline A males & 8.6 & 6.0 & 2.6 & 0.83 & 14 & 11.26 & 0.000 & $\mathrm{p}<.05$ \\
\hline females & 8.7 & 6.1 & 2.6 & 1.10 & 14 & 7.973 & 0.000 & $\mathrm{p}<.05$ \\
\hline B males & 8.6 & 7.4 & 1.2 & 1.09 & 14 & 3.345 & 0.005 & $\mathrm{p}<.05$ \\
\hline females & 8.9 & 7.4 & 1.5 & 1.03 & 14 & 3.744 & 0.002 & $\mathrm{p}<.05$ \\
\hline
\end{tabular}

KEY: MCA - mean chronological age

MMA - mean mental age

M-d - mean difference

SD-d - standard deviation difference df - degrees of freedom

$t-t$ value

p-value - probability values

p-level - probability level

Table 3: Comparison between Group $A$ and Group B for mean MA scores on the RWFS

\begin{tabular}{|l|c|c|c|c|c|c|}
\hline & M-d & SD-d & df & $t$ & p-value & p-level \\
\hline A to B females & -1.293 & 1.260 & 14 & -3.975 & 0.001 & $\mathrm{p}<.05$ \\
\hline A to B males & -1.387 & 1.215 & 14 & -4.419 & 0.001 & $\mathrm{p}<.05$ \\
\hline
\end{tabular}

KEY: M-d - mean difference

SD-d - standard deviation difference

df - degrees of freedom $\mathrm{t}-\mathrm{t}$ value

p-value - probability values

p-level - probability level 
group and sex were not significant $(\mathrm{p}>.05)$

3. Statistical comparison of mean $M A$ and mean $C A$ scores for Groups $A$ and B. It can be seen in Table 2 that there were significant differences $(p<.05)$ between $C A$ and MA scores for both Group A and Group $\mathrm{B}$, as indicated by the results of the Student's t-test. In Group A (Indian), male and female subjects scored a mean MA of 2.6 years lower ( 6.0 and 6.1 respectively) than their mean $C A$ ( 8.6 and 8.7 respectively). In Group B (White), males scored a mean MA of 1.2 years lower than their mean CA (8.6), and females scored a mean MA of 1.5 years lower than their mean CA(8.9). Only six subjects in all obtained MA scores higher than their CA scores.

The results of the t-test comparing the MA scores of Group A to those of Group B presented in Table 3 indicated a significant difference $(p<.05)$ between the groups. Group A performed poorer than Group B for both sexes.

4. Quantitative and qualitative item analysis. For the purposes of the present study it was necessary to determine an arbitrary/subjective cut off point to categorise responses to items as appropriate or inappropriate. Those items correctly named by $50 \%$ or more of the subjects were classified as appropriate and those items correctly named by less than $50 \%$ of the subjects were categorised as inappropriate. These results are presented in Figure 1. Subjects in Group A responded appropriately to 35 items and inappropriately to 15 items while in Group B subjects responded appropriately to 42 items and inappropriately to 8 items (see Figure 1). Items one to 25 were easily named by both groups with the exception of item 18 (suitcase) for Group A (Indian). Items 26 to 50 reflect variable levels of difficulty for the subjects. Seven items (spout,

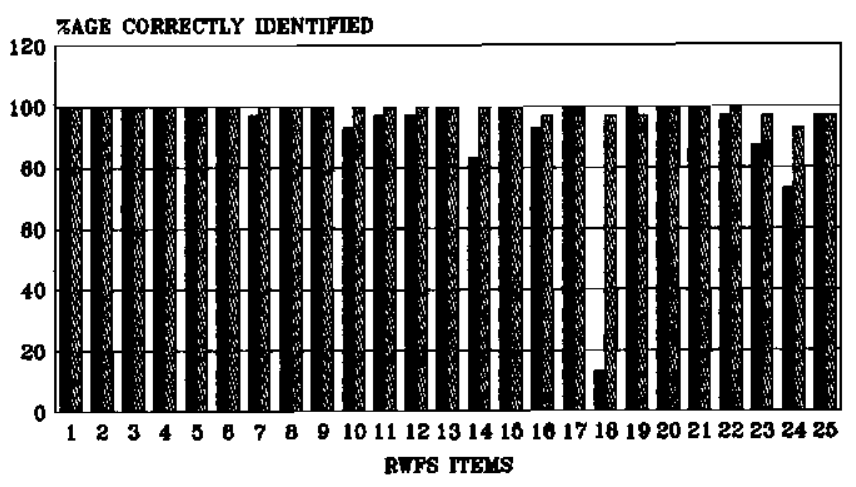

GROUP A AROP G

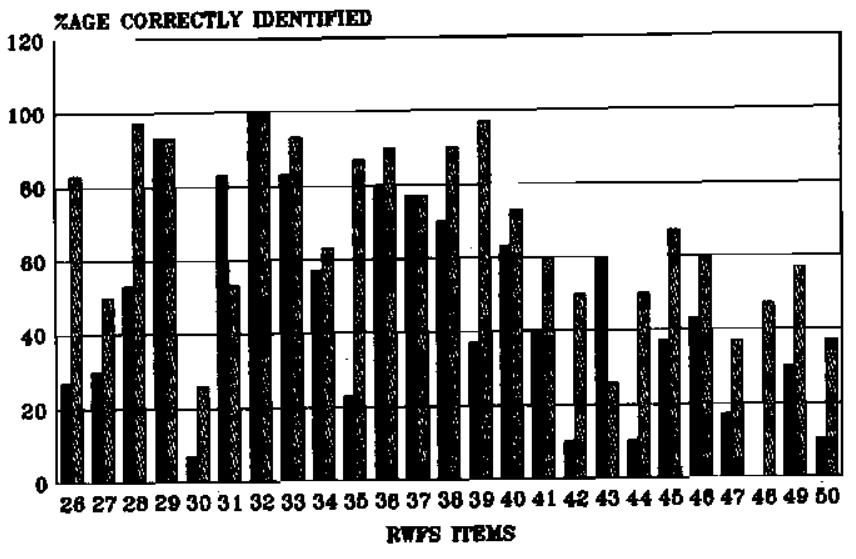

GROUP A GROUP B

Figure 1: Percentage of correct responses given by subjects to each item on RWFS cuff, flame, wick, sling, spire/steeple and hinge) were inappropriately responded to by both groups.

\section{DISCUSSION}

The performance of the two South African groups was significantly lower than the British norms. It appears that differences attributed to the different cultural and ethnic backgrounds of South African Whites and Indians play a significant role in the acquisition of vocabulary. This is consistent with Adler's (1971) observation that the patterns of behaviour unique to specific cultural groups are derived from their ethnic heritage. It therefore appears that ethnic group membership has diverse effects on naming. The suitability of the RWFS for South African Indian and White children is therefore questionable. The implication of only six subjects ( $10 \%)$ obtaining scores equal to or above their chronological age levels, is that all the remainder have expressive vocabularies not commensurate with CA. Another measure of selecting children requiring therapy because of poor expressive vocabularies, is to consider those whose test performance falls below the 25th percentile, or below the middle fifty percent range (Renfrew, 1988). In the present study, 26 subjects from Group $A$, and 13 subjects from Group B could, using the British norms, be diagnosed as having expressive vocabulary problems and could require therapy. All subjects however were judged by their teachers as having normal language abilities, although the subjects were not tested specifically for language problems. The performance of the subjects scoring below the 25 th percentile on the RWFS therefore should be viewed as either different or defective. Depending on the theoretical perspective of individual speech clinicians, either view can be adopted. If the deficit theory is adopted, the presence of a language disorder is suggested which would require intervention. 'Thus, according to Manickam (1985, p.35) "although the individual may be functioning adequately in his [sic] socio-cultural environment, he [sic] is still viewed as being deficient with regard to the norms and is considered a candidate for an intervention programme". On this basis of incorrectly identifying children for therapy, the test itself does not appear to be a suitable assessment procedure. In contrast, results of this study seem to support the difference theory which indicates that because the norms for the RWFS were not established for the population groups investigated, the test norms are inappropriate for these groups. Furthermore, as stated by Adler $(1979$, p. 95$)$, and pertaining to this particular test, "unless a particular test has been standardised on a given group of culturally different people, it is to be expected that the scores of the culturally different will be lower than normal". It seems that because this test was standardised on the British population, and because test items were selected with that population in mind, subjective judgements of its being biased and unfair when used on other population groups would be correct. The RWFS does not appear to be sensitive to dialectal and cultural differences of South African Indian and White groups. 'The need for investigation before making subjective judgements about test suitability is however vital

Although the effect of the sex variable was not found to be statistically significant, the mean scores of males in both groups was one point higher than the mean scores for females. Such a difference is consistent with Renfrew's (1990) scores and with her suggestion that a number of items are more familiar to boys than girls (e.g.tools).

A further aim of the study was to investigate the relevance of specific test items. Difficulty with apparently unclear drawings was noted with "diver" "lighthouse" "hinge" "sling" 
"thermometer" and "pod" (items 40, 28, 50, 47, 45, and 44 respectively). As the test is not one of picture recognition, perhaps these items should be more clearly represented in pictures. Frequent incorrect responses were noted for some items, for example, "nail" for "screw" and "bandage" for "sling". On some items, cultural differences appeared to influence naming responses. The item "spire/steeple" (see item 48 in Figure 1) was correctly named by nearly half of the White children, but was not correctly named by any children in the Indian group. This lexical item thus seems to present a problem to both groups, but especially to the latter group. A lexical item used consistently differently by the two groups of subjects was "suitcase" (see item 18 in Figure 1). In Group A, 87\% of subjects incorrectly identified the picture as "bag" whereas in Group B, $97 \%$ of subjects correctly identified it as "suitcase" or "case". This would seem to indicate a lexical difference between South African Indian English and South African English speakers. In testing, the speech therapist should thus be careful not to assume that target lexical items should be identical among all English speakers.

Overall, the test does not appear to be suitable for use with South African Indian or White children between eight to nine years of age. For the Indian group, scores were so different from the British standardisation sample that it does not seem that the test could be used to differentiate between language difficulties and normal language. For the White group, however, the test could possibly be modified for use. One means of accomplishing this, is to reorder items in terms of level of difficulty as was found to be necessary for the New Zealand edition (C. Renfrew, personal communication, May, 1991). An overview of the items as represented in Figure 1 suggests that reordering item numbers $30,27,43$, and 31 ("cuff" "spout" "wick" and "drill" respectively) towards the end of the test might be a solution.

\section{CONCLUSION}

The present study was aimed at investigating the suitability of the RWFS for South African Indian and White children ages ranging from eight to nine years. This aim was achieved by comparing the performance of the South African children to the British standardisation population. Results revealed significant differences in mean scores between populations due to ethnic group membership as seen on the ANOVA and the ttest. Furthermore, comparisons of mean MAs between Group $A$ and Group B also revealed a significant difference which could be indicative of cultural differences between these groups, as confirmed by an examination of the responses on the item analysis. In its present form the RWFS is not suitable for use as a standardised language tool for assessing expressive vocabulary by South African speech clinicians for the populations investigated. The test could possibly be modified by reordering the sequence of items for the White group, but such modifications do not seem possible for the Indian group.

\section{ACKNOWLEDGEMENTS}

Sincere appreciation is extended to the Directors of Education in the House of Delegates and Natal Education Departments for granting permission to conduct the fieldwork in the schools concerned.

\section{REFERENCES}

Adler, S. (1971). Dialectal differences : Professional clinical implica tions. Journal of Speech and Hearing Disorders, 36, 90-95.

Adler, S. (1979). Poverty children and their language : Implications for teaching and treating. New York: Grune and Stratton.

Alant, E. \& Beukes, S. M. (1986). The application of the revised version of the Peabody Picture Vocabulary Test (PPVT-R) to non-mainstream children. The South African Journal of Communication Disor ders, $3.3,8-9$.

Anderson, J. (1981). Considerations in phonological assessment. In J Erickson \& D. Omark (Eds.), Communication assessment of the bilin gual bicultural child. Baltimore : University Park Press.

Bloom, L. \& Lahey, M. (1978). Language development and language disorders. New York : John Wiley \& Sons.

Cottrell, A. W., Montague, J., Farb, J. \& Thorne, J. M. (1980). An operant procedure for improving vocabulary definition performances in developmentally delayed children. Jou mal of Speech and Hearing Disorders, 55, 90-102.

Downie, N. M. \& Heath, R. W. (Eds.). (1974). Basic statistical methods New York : Harper and Row.

Jensen, A. R. (1980). Bias in mental testing. London : Methuen.

John, V. P. \& Goldstein, L. S. (1964). The social context of language acquisition. Merrill-Palmer Quarterlu, 10, 265-275.

Leonard, L. B. \& Fey, M. E. (1979). The early lexicons of normal and langauge disordered children : Developmental and training considerations. In N. J. I ass (Ed.), Speech and language: Advances in basic research and practice Vol 2. New York : Academic Press.

Malan, K. C. (1981). An investigation of non-standard English syntax in 12 year old Coloured children. The South African Journal of Communication Disorders, 28, 68-80.

Manickam, L. (1985). An investigution into the performance of normal English speaking South African Indian adults on the Peabody Picture Vocabulary Test (1)unn, 1965). Unpublished B. Speech and Hearing Therapy Research Project, University of Durban-Westville.

Owens, R. E. (1988). Language development : An introduction. (2nd ed.) Columbus : Charles E. Merrill.

Rees, N. S. (1980). Learning to talk and understand. In T. S. Hixon, L. D. Shriberg, \& J. H. Saxman (Eds.), Introduction to communication disorders. Englewood Cliffs, N.J. : Prentice Hall.

Renfrew, C. E. (1972). Word Finding Vocabulary Scale. (2nd ed.). Oxford : C. E. Renfrew.

Renfrew, C. E. (1988). Word Finding Vocabulary Scale. (3rd ed.) Oxford : C. E. Renfrew.

Renfrew, C. E. Word Finding Vocabulary Scale. (New Zealand edition). Oxford : C. E, Renfrew.

Taylor, O. (1986). Treatment of communication disorders in culturally and linguistically diverse populations. (Ed.). California : CollegeHill.

Vaughn-Cooke, F. B. (1983). Improving language assessment in minority children. Asha,25, 29-33.

Wiig, E. H. \& Semel, E. M. (1984). Language assessment and intervention for the learning disabled. Iondon : Charles E. Merrill.

Williams, F. (Ed.). (1970). Language and povertu. Chicago: Markham. 